\title{
Distribución de clorofila y producción primaria por clases de tamaño en la costa del Pacífico mexicano
}

\section{Distribution of chlorophyll and primary production by size classes along the Mexican Pacific coast}

\author{
José Rubén Lara-Lara* \\ Carmen Bazán-Guzmán \\ Centro de Investigación Científica y de Educación Superior de Ensenada \\ Km 107 Carretera Tijuana-Ensenada \\ Ensenada, Baja California, México \\ *E-mail: rlara@cicese.mx
}

Recibido en marzo de 2004; aceptado en julio de 2004

\section{Resumen}

Del 15 de enero al 4 de febrero de 1999, se realizó un crucero oceanográfico a lo largo de la costa oeste de México, desde la boca del Golfo de California hasta el Golfo de Tehuantepec. Por primera ocasión en esta región, se realizaron experimentos de asimilación de ${ }^{14} \mathrm{C}$ y se determinó el contenido de clorofila $a$ en cuatro clases de tamaño en siete estaciones. También se determinaron las concentraciones de nutrientes $\left(\mathrm{PO}_{4}\right.$ y $\left.\mathrm{SiO}_{2}\right)$. Las nutriclinas fueron muy superficiales, generalmente dentro de la zona eufótica. La temperatura superficial varió entre $19.5^{\circ} \mathrm{C}$ y $28.3^{\circ} \mathrm{C}$, desde la boca del Golfo de California hasta el Golfo de Tehuantepec. La clorofila $a$ integrada a través de la zona eufótica varió dentro de 16.8 y $95.6 \mathrm{mg} \mathrm{m}^{-2}(\bar{x}=41.4)$. La producción primaria integrada diaria tuvo un rango de 0.16 a $1.15 \mathrm{~g} \mathrm{C} \mathrm{m}^{-2} \mathrm{~d}^{-1}(\bar{x}=0.53)$. El nanofitoplancton $(<20 \mu \mathrm{m})$ presentó la mayor contribución a la clorofila y producción primaria (60-100\%). El microfitoplancton ( $>20 \mu \mathrm{m})$ tuvo una contribución significativa sólo en dos estaciones de la región sur (30\% y 44\%). La contribución por las clases de tamaño intermedias dentro del nanofitoplancton $(<20 \mathrm{a}>10 \mu \mathrm{m},<10 \mathrm{a}>3 \mu \mathrm{m})$ y el picoplancton $(<3 \mathrm{a}>0.45 \mu \mathrm{m})$ fue variable. La producción primaria y el contenido de clorofila $a$ mostraron un claro patrón de distribución espacial incrementándose de las estaciones del norte hacia el sur.

Palabras clave: producción primaria, clorofila, clases de tamaño, México, Océano Pacífico oriental.

\begin{abstract}
From 15 January to 4 February, 1999, we carried out an oceanographic cruise along the west coast of Mexico, from the mouth of the Gulf of California to the Gulf of Tehuantepec. For the first time in this region, size-fractionated chlorophyll $a$ and ${ }^{14} \mathrm{C}$ assimilation experiments were carried out at seven stations. Nutrient concentrations $\left(\mathrm{PO}_{4}\right.$ and $\left.\mathrm{SiO}_{2}\right)$ were also measured. Nutriclines were very shallow and developed within the euphotic zone depth. Sea surface temperature varied from $19.5^{\circ} \mathrm{C}$ at the mouth of the Gulf of California to $28.3^{\circ} \mathrm{C}$ in the Gulf of Tehuantepec. The integrated euphotic zone chlorophyll $a$ ranged from 16.8 to $95.6 \mathrm{mg} \mathrm{m}^{-2}(\bar{x}=41.4)$. Daily integrated primary production rates ranged from 0.16 to $1.15 \mathrm{~g} \mathrm{C} \mathrm{m}^{-2} \mathrm{~d}^{-1}(\bar{x}=0.53)$. Nanophytoplankton $(<20 \mu \mathrm{m})$ contributed most to both chlorophyll and primary production (60-100\%). Microphytoplankton $(>20 \mu \mathrm{m})$ was significant only at two southern stations ( 30\% and $44 \%)$. The contribution by the nanophytoplankton size fractions ( $<20$ to $>10 \mu \mathrm{m}$ and $<10$ to $>3 \mu \mathrm{m}$ ) and the picoplancton $(<3$ to $>0.45 \mu \mathrm{m})$ was variable. Phytoplankton biomass and primary production rates showed a clear spatial pattern, increasing from north to south.
\end{abstract}

Key words: primary production, chlorophyll, size classes, Mexico, eastern Pacific Ocean.

\section{Introducción}

Existen pocas estimaciones de producción primaria y biomasa de fitoplancton (contenido de clorofila $a$ ) para las aguas costeras a lo largo de la región sur de México. Leet y Stevenson (1969) proporcionaron los primeros datos de producción primaria superficial para la región entre Mazatlán, Cabo San Lucas y las islas Tres Marías. Fuera de la costa sur de México, en el Pacifico oriental tropical, Owen y Zeitzschel (1970) reportaron la máxima producción a principios de la primavera, y un máximo secundario a finales de verano.

\section{Introduction}

Phytoplankton biomass (chlorophyll $a$ content) and primary production data for the coastal waters along the southern region of Mexico are very scarce. Leet and Stevenson (1969) reported the first surface primary productivity data for the region between Mazatlán, Cabo San Lucas and the Tres Marías islands. Off the southern coast of Mexico in the eastern tropical Pacific, Owen and Zeitzschel (1970) recorded maximum production in early spring and a secondary peak in late summer. Gaxiola-Castro and Álvarez-Borrego (1986) reported 
Gaxiola-Castro y Álvarez-Borrego (1986) presentaron valores de producción integrada para el mes de enero en un transecto desde enfrente de la boca del Golfo de California hasta frente a Acapulco. Posteriormente, Robles-Jarero y Lara-Lara (1993) estudiaron la variabilidad espacial de la biomasa y la producción primaria para el Golfo de Tehuantepec. Durante todos estos estudios se ha demostrado que tanto la biomasa como la producción primaria del fitoplancton es alta a pesar de ser ésta una zona subtropical.

Estudios de la variabilidad y distribución de biomasa y productividad de fitoplancton por clases de tamaño han mostrado las importantes implicaciones del tamaño celular en el ciclo bioquímico del carbono y en la estructura de la red trófica pelágica (Walsh, 1976; Malone, 1980). Varios estudios han mostrado la significativa contribución (hasta 90\%) del nanofitoplancton (células $<20 \mu \mathrm{m}$ ) a la biomasa total y a la producción primaria (Malone, 1971; Platt et al., 1983; Glover et al., 1985; Hopcroft y Roff, 1990). Se ha demostrado también que, en general, es mayor la producción del nanofitoplancton en aguas oceánicas, y la del microfitoplancton ( $>20 \mu \mathrm{m})$ lo es en aguas neríticas (Malone, 1980; Cole et al., 1986; Harris et al., 1991).

En este trabajo se presentan por primera vez, estimaciones sobre la distribución de la biomasa (contenido de clorofila $a$ ) y producción del fitoplancton por clases de tamaño para un transecto entre la boca del Golfo de California y el Golfo de Tehuantepec. El objetivo principal fue entender la variabilidad espacial de la biomasa y la producción del fitoplancton en una región del Pacífico costero mexicano que ha sido pobremente estudiada.

\section{Área de estudio}

El área de estudio incluyó un transecto desde la boca del Golfo de California (estación 137 a los $22^{\circ} 39^{\prime}$ N, 108 $44^{\prime}$ W)

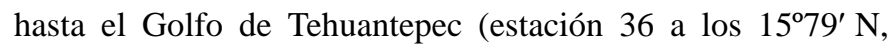
$93^{\circ} 14.84^{\prime}$ W) (fig. 1). Se ubicaron cinco estaciones fuera de la plataforma continental a profundidades que variaron de 1225 a $3500 \mathrm{~m}$. Las otras dos estaciones fueron localizadas en el Golfo de Tehuantepec a profundidades que variaron entre $60 \mathrm{y}$ $174 \mathrm{~m}$.

\section{Métodos}

Se realizaron experimentos de producción primaria y mediciones del contenido de clorofila $a$ por clases de tamaño en siete estaciones durante el crucero Tehuanos II, a bordo del B/O El Puma, del 15 de enero al 4 de febrero de 1999. En cada estación se registraron las distribuciones verticales de temperatura y salinidad por medio de un CTD (Neil Brown Smart). Las muestras de agua de mar fueron recolectadas con botellas Niskin de 7 y $3 \mathrm{~L}$, a cinco profundidades, correspondientes al $100 \%, 60 \%, 22 \%, 6 \%$ y $1 \%$ de la irradiancia medida en la superficie (Eo). Los perfiles de irradiancia fueron integrated primary production values obtained in January for one transect from the mouth of the Gulf of California to the offshore waters of Acapulco. Robles-Jarero and Lara-Lara (1993) studied the spatial variability of the biomass and primary production for the southernmost area of Mexico, the Gulf of Tehuantepec. In all these studies it has been shown that phytoplankton biomass and production rates are high even though this is a subtropical region.

Studies of the variability and distribution of sizefractionated phytoplankton biomass and primary production have shown the important implications of cell size in the biogeochemical carbon cycle and in the pelagic food chain structure (Walsh, 1976; Malone, 1980). Several studies have shown the significant contribution (up to 90\%) of nanophytoplankton (cells $<20 \mu \mathrm{m}$ ) to total biomass and production (Malone, 1971; Platt et al., 1983; Glover et al., 1985; Hopcroft and Roff, 1990). It has been also reported (Malone, 1980; Cole et al., 1986; Harris et al., 1991) that, in general, nanophytoplankton production is higher in oceanic waters and that of microphytoplankton $(>20 \mu \mathrm{m})$ in neritic waters.

We report here, for the first time, the distribution of phytoplankton biomass (chlorophyll $a$ content) and primary production by size classes for one transect from the mouth of the Gulf of California to the Gulf of Tehuantepec. The main objective is to understand the spatial variability of the phytoplankton biomass and primary production by size classes in a poorly-studied region along the Mexican Pacific coast.

\section{Study area}

The study area included a transect from the mouth of the Gulf of California (station 137 at $22^{\circ} 39^{\prime} \mathrm{N}, 108^{\circ} 44^{\prime} \mathrm{W}$ ) to the Gulf of Tehuantepec (station 36 at $15^{\circ} 79^{\prime} \mathrm{N}, 93^{\circ} 14.84^{\prime} \mathrm{W}$ ) (fig. 1). Five stations were located off the shelf at bottom

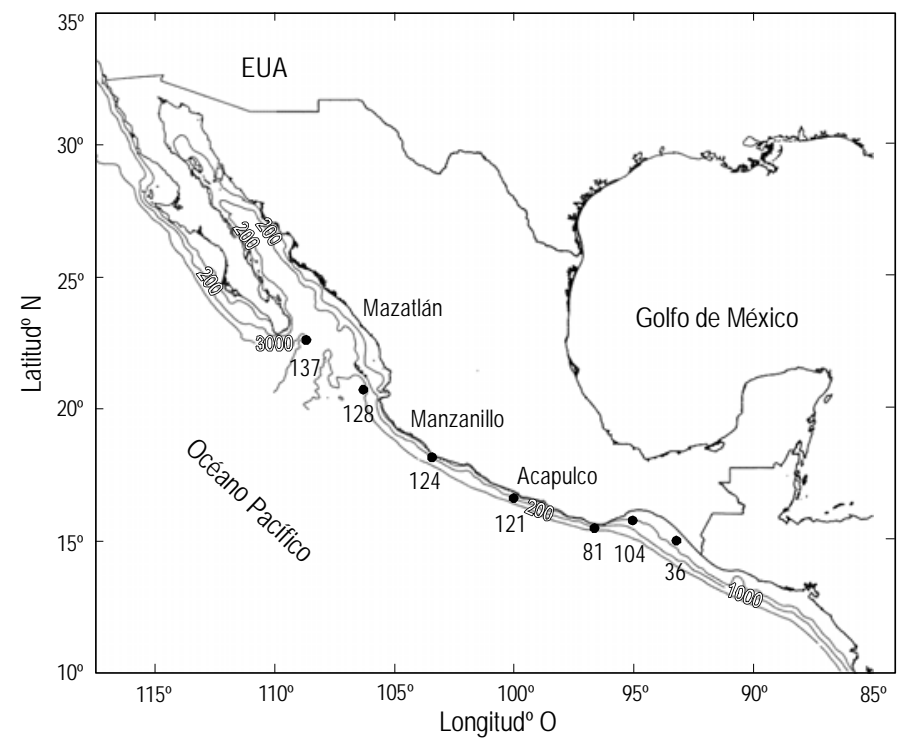

Figura 1. Localización de las estaciones en el área de estudio. Figure 1. Location of the stations in the study area. 
determinados mediante un fotómetro submarino, dentro del espectro visible en $\mathrm{cal} \mathrm{cm}^{-2}$ (Khalsico 268WA310).

Las muestras de agua de mar para los experimentos de producción primaria fueron filtradas a través de una malla de $200 \mu \mathrm{m}$ para eliminar el mesozooplancton. Después, las muestras de cada profundidad fueron colocadas en cinco botellas de $125 \mathrm{~mL}$ e inoculadas por duplicado con $5 \mu \mathrm{Ci}$ de $\mathrm{NaH}^{14} \mathrm{CO}_{3}$. Las incubaciones fueron realizadas a bordo del barco entre las 11:00 y las 13:00 h para obtener la máxima irradiancia incidente, siguiendo el método de Steemann-Nielsen (1952). Las muestras se enfriaron con agua de mar superficial, y los niveles de irradiancia a profundidad se simularon con mallas que permiten el paso de la luz con diferentes intensidades. Después de la incubación, dos muestras de cada profundidad fueron filtradas a través de filtros de membrana de $25 \mathrm{~mm}$ de diámetro y de $0.45 \mu \mathrm{m}$ de tamaño de poro, para obtener la comunidad total; otras dos muestras fueron filtradas a través de una malla Nitex de $20 \mu \mathrm{m}$ para separar la fracción del nanofitoplancton. La contribución por el microfitoplancton $(>20 \mu \mathrm{m})$ fue calculada sustrayendo las tasas de productividad o las concentraciones de clorofila de la fracción del nanofitoplancton del total. Además, la fracción del nanofitoplancton fue separada en dos fracciones más pequeñas. La subfracción de $<20 \mu \mathrm{m}$ a $>10 \mu \mathrm{m}$ fue filtrada a través de una malla Nitex de $10 \mu \mathrm{m}$; la subfracción $<10 \mu \mathrm{m}$ a $>3 \mu \mathrm{m}$ y el picoplancton $(<3 \mu \mathrm{m}$ a $>0.45 \mu \mathrm{m}$ ) fueron separados usando filtros de membrana de $25 \mathrm{~mm}$ de diámetro de $3 \mathrm{y}$ $0.45 \mu \mathrm{m}$ de tamaño de poro.

Los filtros marcados con ${ }^{14} \mathrm{C}$ fueron colocados en viales con $15 \mathrm{~mL}$ de solución de centelleo (Betaphase). La radioactividad fue medida con un contador de centelleo líquido Beckman LSC100. Los cálculos del carbono inorgánico disuelto en el agua de mar y la asimilación de carbono fueron realizados de acuerdo con Strickland y Parsons (1972). Para cada profundidad muestreada también se midieron el contenido de clorofila $a$ por clases de tamaño y las concentraciones de nutrientes $\left(\mathrm{PO}_{4}\right.$ y $\left.\mathrm{SiO}_{2}\right)$. Los nutrientes fueron medidos de muestras congeladas, mediante un autoanalizador Technicon y un espectrofotómetro Spectronic 1001, según los métodos descritos por Grashoff et al. (1983). Los limites mínimos de detección son $0.01 \mu \mathrm{M}$ para $\mathrm{PO}_{4}$ y $0.1 \mu \mathrm{M}$ para $\mathrm{SiO}_{2}$. Los contenidos de clorofila $a$ total y por clases de tamaño fueron medidos siguiendo la técnica fluorimétrica de Yentsch y Menzel (1963), mediante un fluorómetro Turner Design 10, corrigiendo por feopigmentos. El protocolo de fraccionación para la clorofila fue similar al usado para la producción primaria. Las profundidades de las termoclinas y nutriclinas se definieron a la profundidad en donde ocurrieron cambios rápidos de temperatura y concentraciones de nutrientes en los perfiles verticales respectivos. Para obtener la producción primaria diaria se midió la intensidad de luz superficial a intervalos de una hora durante el día-luz, después la producción de las dos horas se extrapolo al día-luz para obtener las tasas diarias de producción. depths that varied from 1225 to $3500 \mathrm{~m}$, and two stations were located in the Gulf of Tehuantepec at bottom depths that varied from 60 to $174 \mathrm{~m}$.

\section{Methods}

Size-fractionated primary production experiments and chlorophyll $a$ measurements were carried out at seven stations during the Tehuanos II cruise on board the R/V El Puma from 15 January to 4 February, 1999. Vertical distributions of temperature and salinity at each station were registered by CTD (Neil Brown Smart) casts. Seawater samples were collected with 7- and 3-L Niskin bottles at five depths corresponding to $100 \%, 60 \%, 22 \%, 6 \%$ and $1 \%$ irradiance measured just below the sea surface (Eo). Subsurface irradiance profiles were determined with a Khalsico 268WA310 submarine photometer, within the visible spectrum in cal $\mathrm{cm}^{-2}$.

Seawater samples for primary production experiments were filtered through a $200-\mu \mathrm{m}$ Nitex mesh to remove the large mesozooplankton. Immediately thereafter, the samples from each depth were placed in five $125-\mathrm{mL}$ clear bottles inoculated in duplicate with $5 \mu \mathrm{Ci}$ of $\mathrm{NaH}^{14} \mathrm{CO}_{3}$. Incubations were performed aboard ship between 11:00 and 13:00 h to obtain maximum incident irradiance, following the method of Steemann-Nielsen (1952). Samples were cooled with surface seawater. Irradiance levels at depth were simulated with meshes that permit the input of light at different intensities. After incubation, two samples of each depth were filtered through $0.45-\mu \mathrm{m}$ pore-size membrane filters of $25-\mathrm{mm}$ diameter to obtain the total community; two other samples were filtered through a $20-\mu \mathrm{m}$ Nitex mesh to separate the nanophytoplankton fraction. The contribution by the microphytoplankton $(>20 \mu \mathrm{m})$ was calculated by subtracting the rates or chlorophyll $a$ concentrations of the nanophytoplankton fraction from the total. The nanophytoplankton fraction was further separated into two smaller fractions. The largest subfraction $(<20 \mu \mathrm{m}$ to $>10 \mu \mathrm{m})$ was filtered through a $10-\mu \mathrm{m}$ Nitex mesh, and the other fraction ( $<10 \mu \mathrm{m}$ to $>3 \mu \mathrm{m})$ and the picoplancton $(<3 \mu \mathrm{m}$ to $>0.45 \mu \mathrm{m}$ ) were separated using 3 - and $0.45-\mu \mathrm{m}$ pore-size membrane filters of 25 -mm diameter.

The filters labeled with ${ }^{14} \mathrm{C}$ were put into scintillation vials with $15 \mathrm{~mL}$ of Betaphase cocktail. Radioactivity was measured with a Beckman LSC-100 liquid scintillation counter. Calculations for the amount of inorganic carbon in seawater and the carbon assimilation were done according to Strickland and Parsons (1972). For each sample depth, we also measured sizefractionated chlorophyll $a$ contents and nutrient concentrations $\left(\mathrm{PO}_{4}\right.$ and $\left.\mathrm{SiO}_{2}\right)$. Nutrients were measured from frozen samples with a Scientific Instrument autoanalyzer and a Spectronic 1001 spectrophotometer, following the methods of Grasshoff et al. (1983). The minimum detection limits were $0.01 \mu \mathrm{M}$ for $\mathrm{PO}_{4}$ and $0.1 \mu \mathrm{M}$ for $\mathrm{SiO}_{2}$. Total chlorophyll $a$ content and content by size classes were measured following the Yentsch and Menzel (1963) fluorometric technique with a Turner Design 10 fluorometer, and correcting for phaeopigments. The 
Tabla 1. Variaciones de las profundidades de la zona eufótica, las termoclinas y las nutriclinas, y velocidad del viento. Valores máximos de clorofila a y producción primaria. Los niveles de irradiancia in situ para las máximas concentraciones se muestran entre paréntesis.

Table 1. Variations of the euphotic zone, thermocline and nutricline depths, and wind speed. Maximum peaks of chlorophyll $a$ and primary production. In situ irradiance levels for maximum concentrations are given in parentheses.

\begin{tabular}{|c|c|c|c|c|c|c|c|}
\hline \multirow[t]{2}{*}{ Estación } & \multirow{2}{*}{$\begin{array}{l}\text { Zona eufótica } \\
\text { (m) }\end{array}$} & \multirow{2}{*}{$\begin{array}{l}\text { Termoclinas } \\
\text { (m) }\end{array}$} & \multicolumn{2}{|c|}{ Nutriclinas (m) } & \multirow{2}{*}{$\begin{array}{l}\text { Velocidad } \\
\text { del viento } \\
\left(\mathrm{m} \mathrm{s}^{-1}\right)\end{array}$} & \multirow{2}{*}{$\begin{array}{c}\text { Máxima concentración } \\
\text { de clorofila } a \\
\left(\mathrm{mg} \mathrm{m}^{-3}\right)\end{array}$} & \multirow{2}{*}{$\begin{array}{l}\text { Máximo de } \\
\text { producción primaria } \\
\left(\mathrm{mg} \mathrm{C} \mathrm{m}^{-3} \mathrm{~h}^{-1}\right)\end{array}$} \\
\hline & & & $\mathrm{PO}_{4}(\mu \mathrm{M})$ & $\mathrm{SiO}_{2}(\mu \mathrm{M})$ & & & \\
\hline 36 & 45 & 10 & 15 & 28 & - & $0.72(22)$ & $4.36(22)$ \\
\hline 104 & 48 & 10 & 6 & 6 & 11.5 & $2.06(22)$ & $10.13(22)$ \\
\hline 81 & 52 & 5 & 7 & 32 & 1.5 & $3.78(22)$ & $14.12(22)$ \\
\hline 121 & 66 & 20 & 22 & 40 & 5.8 & $1.92(22)$ & $10.43(60)$ \\
\hline 124 & 32 & 20 & 20 & 11 & 5.8 & 2.17 (6) & $5.79(22)$ \\
\hline 128 & 30 & 20 & 10 & 18 & 7.8 & $1.11(22)$ & $3.50(6)$ \\
\hline 137 & 64 & 40 & 21 & 21 & 13.6 & $0.54(22)$ & $1.78(22)$ \\
\hline
\end{tabular}

\section{Resultados}

\section{Ambiente físico}

Durante el periodo de estudio, los vientos fueron principalmente del norte y noroeste. La velocidad media del viento fue de $7.67 \mathrm{~m} \mathrm{~s}^{-1}$ con un máximo de $13.6 \mathrm{~m} \mathrm{~s}^{-1}$ (tabla 1). En general, durante nuestro estudio los vientos fueron moderados. La temperatura superficial del agua (fig. 2) varió de un mínimo de $19.5^{\circ} \mathrm{C}$ en la estación 137 (boca del golfo) a un máximo de $28.3^{\circ} \mathrm{C}$ en la estación 36 en la región más al sur. En general, las termoclinas se desarrollaron alrededor de los $20 \mathrm{~m}$ de profundidad en las tres estaciones más al sur. La profundidad de la zona eufótica fue aproximadamente de $48 \mathrm{~m}$ con un intervalo de 30 a $66 \mathrm{~m}$. El valor de la zona eufótica más profunda fue registrado en la estación 121 y el más superficial en la estación 128 (tabla 1).

\section{Distribución vertical de las variables químicas y biológicas}

Los fosfatos superficiales variaron de 0.20 a $0.84 \mu \mathrm{M}$, y los silicatos de 0.6 a $5.14 \mu \mathrm{M}$. Las distribuciones verticales de ambos nutrientes (fig. 3) fueron muy similares para todas las estaciones. Las nutriclinas se registraron a profundidades muy superficiales dentro de la zona eufótica ( $20 \mathrm{~m}$ ) (tabla 1). Las distribuciones verticales de clorofila $a$ y producción primaria (figs. 4, 5) mostraron patrones muy similares. En general, los máximos valores de clorofila $a$ y producción primaria se alcanzaron al mismo nivel de irradiancia (22\% Eo), alrededor de $20 \mathrm{~m}$ de profundidad. El nanofitoplancton (células $<20 \mu \mathrm{m}$ ) fue la fracción dominante en todas las estaciones. Dentro de las fracciones de tamaño del nanofitoplancton, la fracción de $<20 \mu \mathrm{m}$ a $>10 \mu \mathrm{m}$ tuvo la mayor contribución a la clorofila y la producción primaria total en las estaciones de la 36 a la 121. Sólo en la estación 137 (boca del golfo) el picoplancton $(<3 \mu \mathrm{m}$ a $>0.45 \mu \mathrm{m})$ tuvo una mayor contribución. chlorophyll size fractionation protocol was similar to that used for ${ }^{14} \mathrm{C}$. Thermoclines and nutriclines were defined as the depths where rapid changes in temperature and nutrients occur in the vertical distributions of these properties. To estimate the daily primary production we measured the surface light intensity every $2 \mathrm{~h}$ during daylight, and then the 2-h production was extrapolated to the daylight hours to get the daily production rates.

\section{Results}

\section{Physical environment}

During the period of study, winds were mainly from the north and northwest, and moderate. The mean wind speed was $7.67 \mathrm{~m} \mathrm{~s}^{-1}$, with a maximum of $13.6 \mathrm{~m} \mathrm{~s}^{-1}$ (table 1 ). Sea surface temperature (fig. 2) varied from a minimum of $19.5^{\circ} \mathrm{C}$ at station 137 at the mouth of the Gulf of California to a maximum of $28.3^{\circ} \mathrm{C}$ at station 36 , the southernmost station of our study area. In general, thermoclines started at around $20 \mathrm{~m}$ depth at the three southernmost stations. The euphotic zone depth averaged $48 \mathrm{~m}$ and ranged from 30 to $66 \mathrm{~m}$. The value of the deepest euphotic zone was registered at station 121 and the shallowest at station 128 (table 1).

\section{Vertical distribution of chemical and biological variables}

Surface phosphates varied from 0.20 to $0.84 \mu \mathrm{M}$, and silicates from 0.6 to $5.14 \mu \mathrm{M}$. Vertical distributions for both nutrients (fig. 3) were very similar for all stations. Nutriclines started at very shallow depths within the euphotic zone $(\sim 20 \mathrm{~m})$ (table 1$)$. The vertical distributions of chlorophyll $a$ and primary production (figs. 4,5$)$ showed very similar patterns. In general, maximum chlorophyll $a$ and production values were reached at the same irradiance level (22\% Eo), around $20 \mathrm{~m}$ depth. Nanophytoplankton (cells $<20 \mu \mathrm{m}$ ) was the dominant fraction at all stations. Within the nanophytoplankton, the $<20 \mu \mathrm{m}$ to $>10 \mu \mathrm{m}$ fraction contributed most to the 


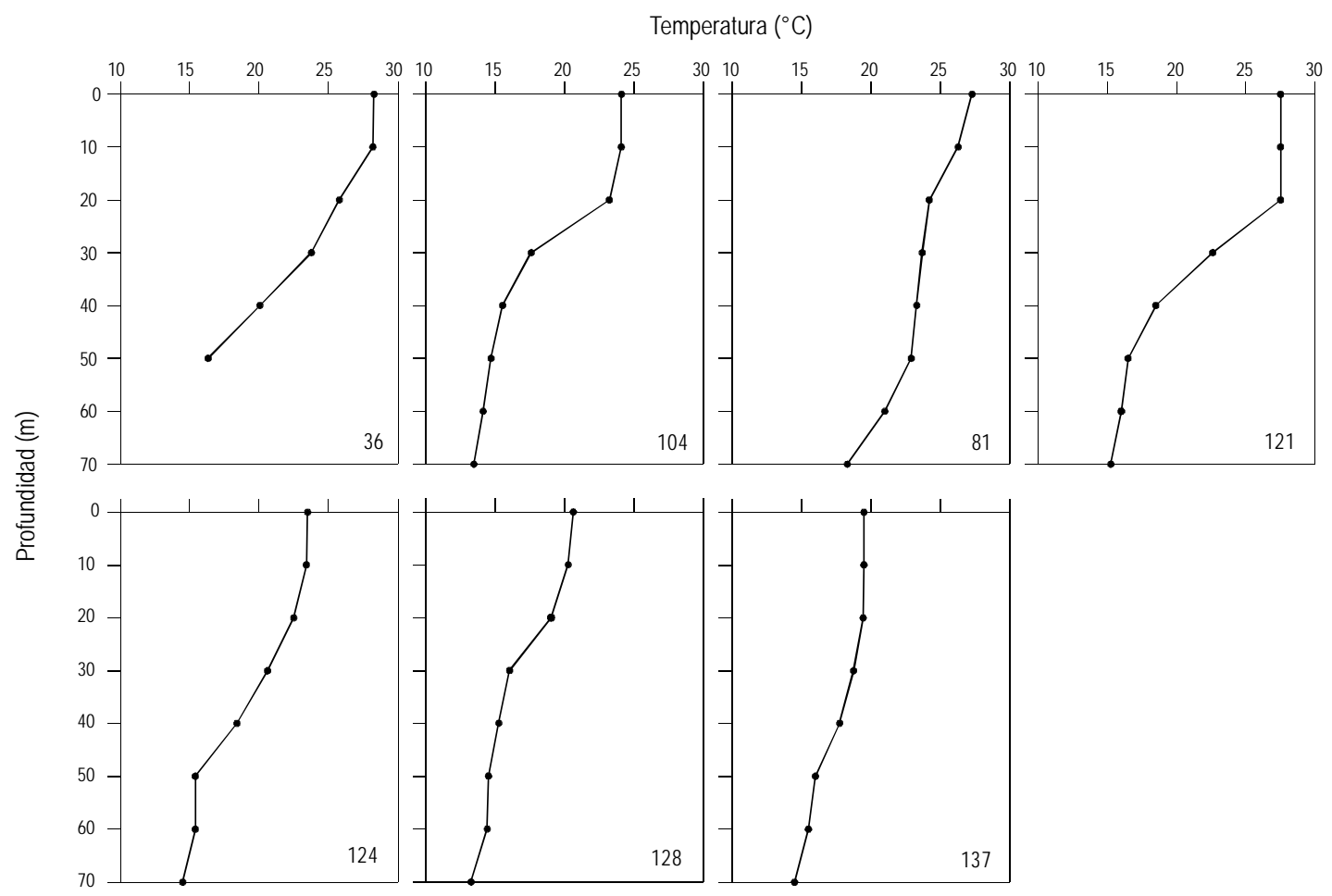

Figura 2. Distribuciones verticales de temperatura $\left({ }^{\circ} \mathrm{C}\right)$ en las estaciones de muestreo.

Figure 2. Vertical distribution of temperature $\left({ }^{\circ} \mathrm{C}\right)$ at the sampling stations.

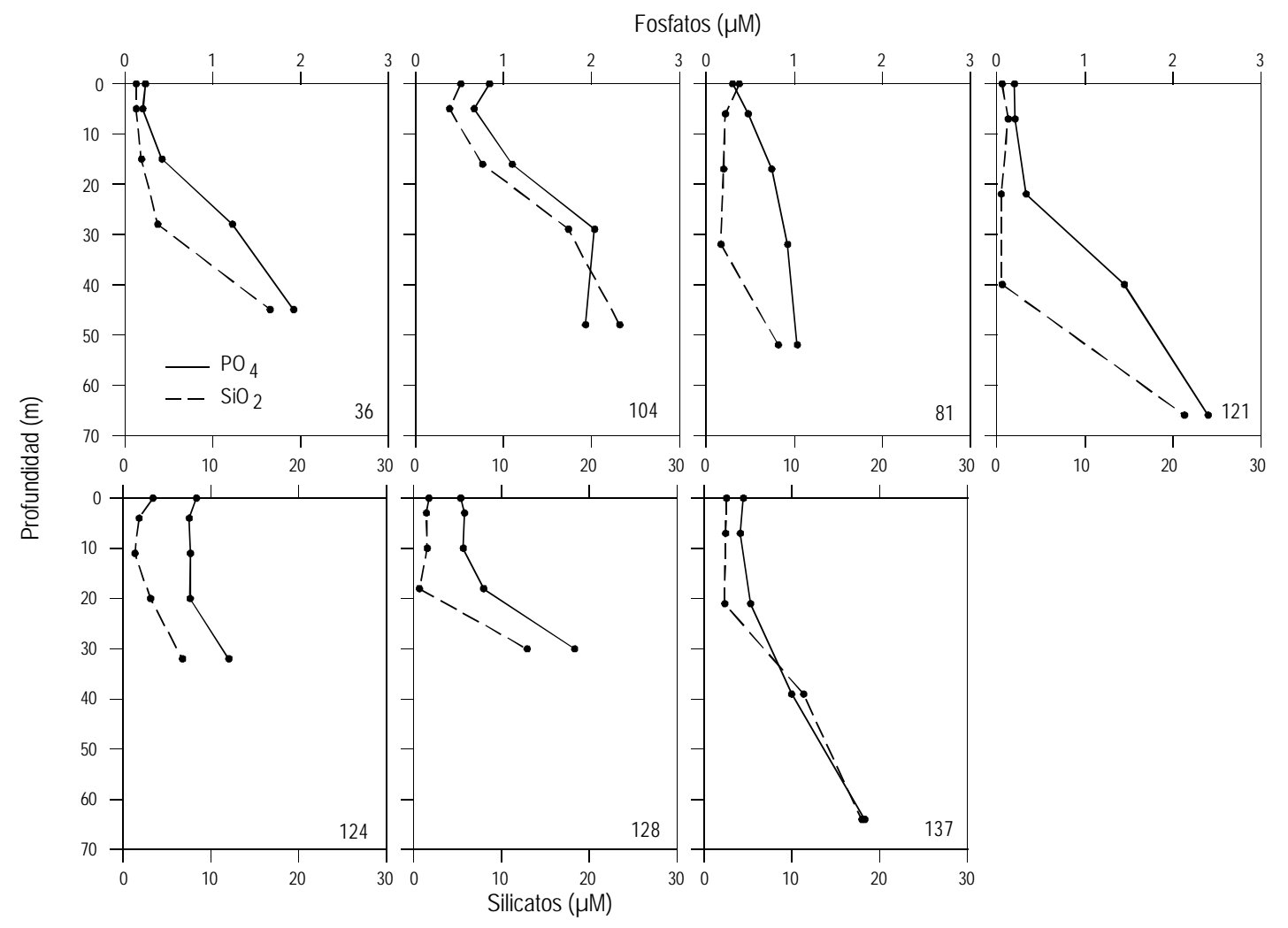

Figura 3. Distribuciones verticales de $\mathrm{PO}_{4}(-)$ y $\mathrm{SiO}_{2}(---)$ en las estaciones de muestreo.

Figure 3. Vertical distribution of $\mathrm{PO}_{4}(-)$ and $\mathrm{SiO}_{2}(---)$ at the sampling stations. 


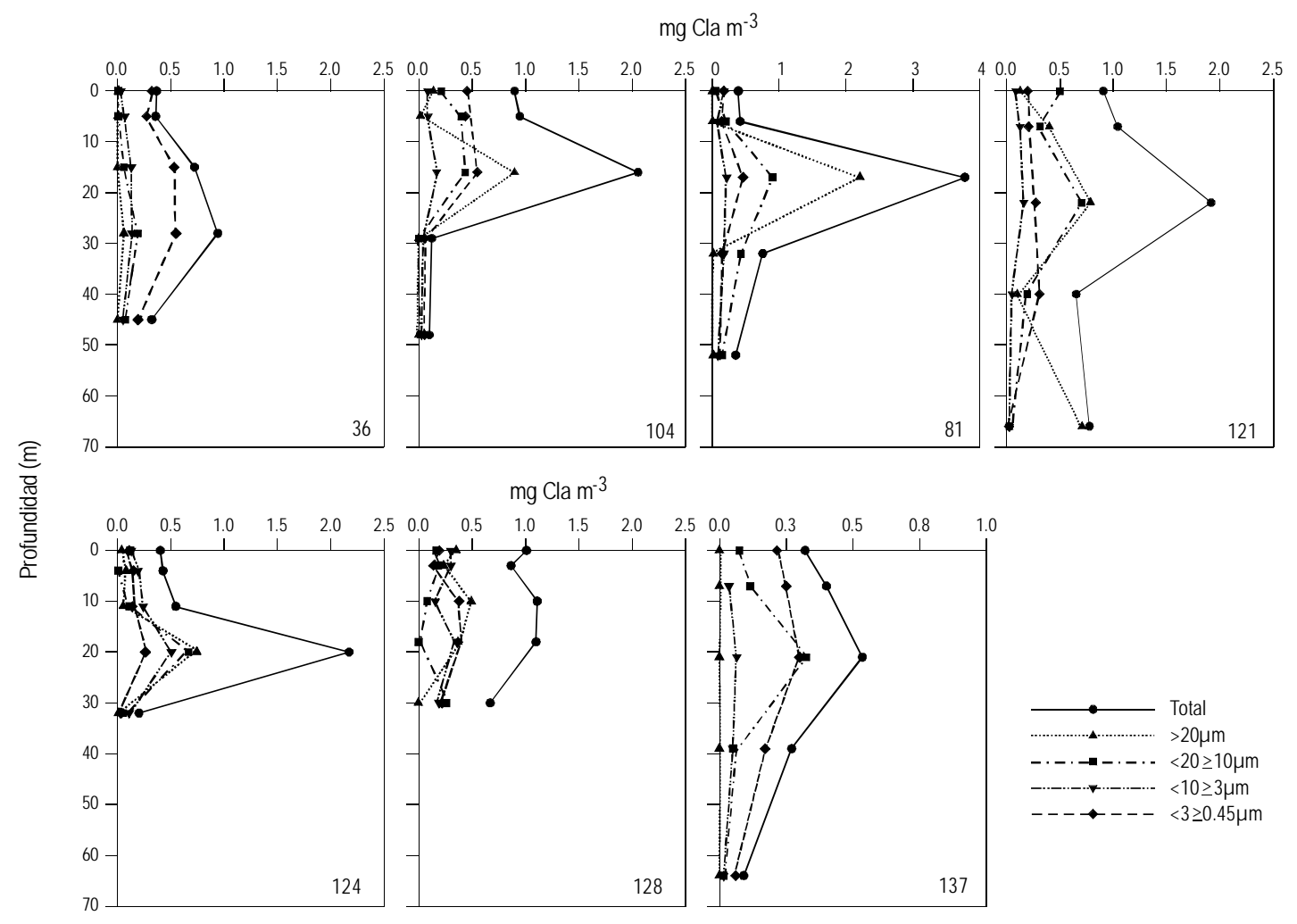

Figura 4. Distribuciones verticales de clorofila $a$.

Figure 4. Vertical distribution of chlorophyll $a$.

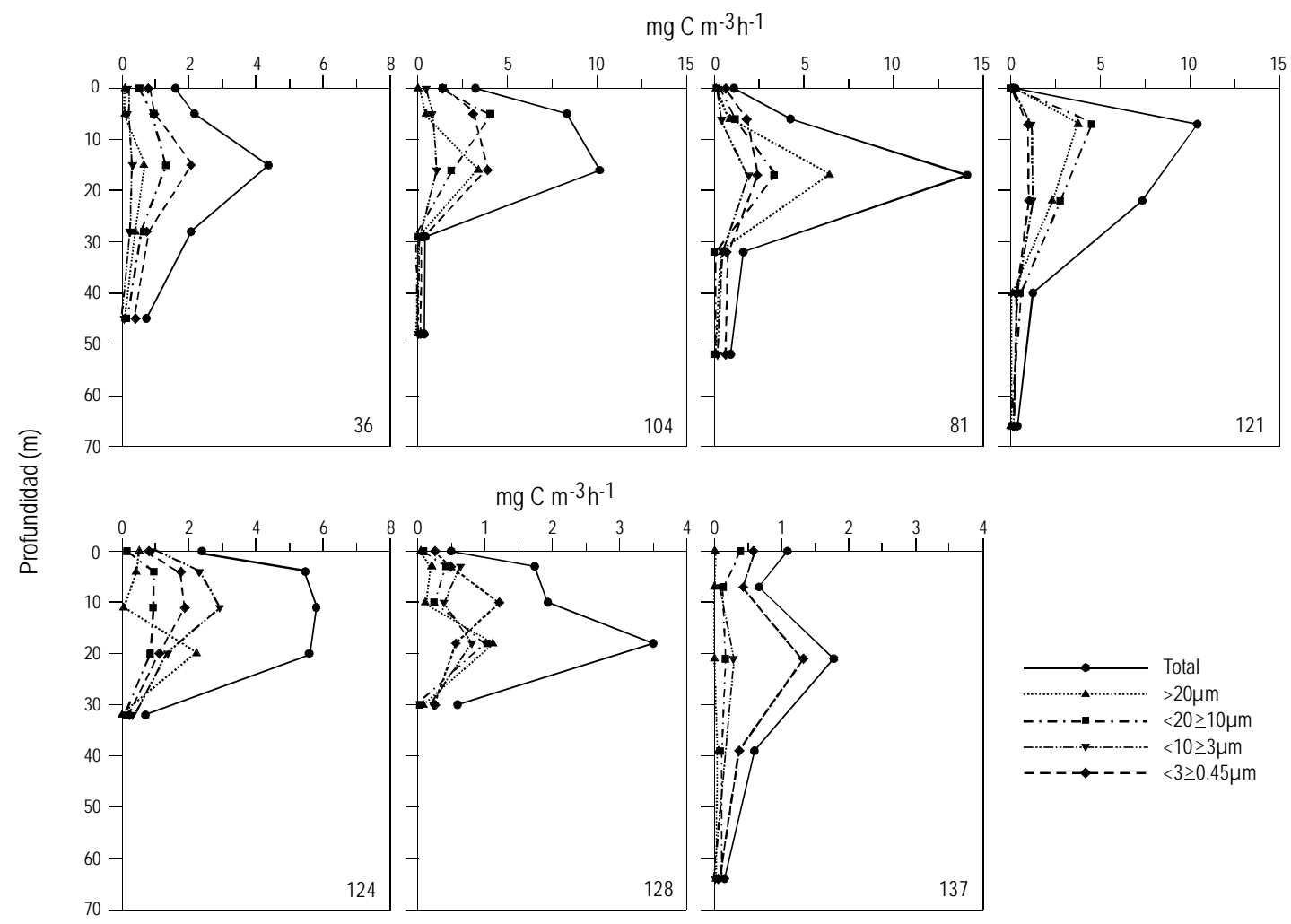

Figura 5. Distribuciones verticales de la producción primaria.

Figure 5. Vertical distribution of primary production. 
Lara-Lara y Bazán-Guzmán: Producción primaria en la costa del Pacífico mexicano

\section{Variabilidad espacial de clorofila a y producción primaria}

La clorofila $a$ total tuvo un rango de 0.09 a $3.8 \mathrm{mg} \mathrm{Cla} \mathrm{\textrm {m } ^ { - 3 }}$

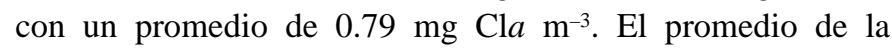
producción primaria total fue de $3.07 \mathrm{mg} \mathrm{C} \mathrm{m}^{-3} \mathrm{~h}^{-1}$ y varió de 0.15 a $17.1 \mathrm{mg} \mathrm{C} \mathrm{m}^{-3} \mathrm{~h}^{-1}$. Las máximas concentraciones de clorofila $a$ y los valores de producción primaria se incrementaron de norte a sur (estaciones 137 a 36). En todas las estaciones el nanofitoplancton contribuyó con el mayor porcentaje del contenido de clorofila $a(60-100 \%)$ y de la producción primaria (70-100\%).

\section{Valores integrados de clorofila a y producción primaria}

El contenido de clorofila $a$ integrado a través de la zona

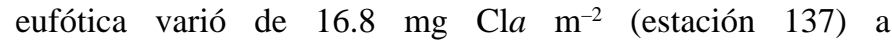

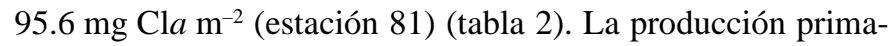
ria diaria presentó un rango de $0.15 \mathrm{~g} \mathrm{C} \mathrm{m}^{-2} \mathrm{~d}^{-1}$ (estación 137) a $1.15 \mathrm{~g} \mathrm{C} \mathrm{m}^{-2} \mathrm{~d}^{-1}$ (estación 81) (tabla 2). El nanofitoplancton tuvo la mayor contribución en todas las estaciones. El microfitoplancton fue importante ( 44\%) únicamente en las estaciones 81 y 121. La contribución de las fracciones del nanofitoplancton fue variable; sin embargo, el picoplancton tuvo su máxima contribución ( 70\%) en la estación 137 en la boca del golfo (tablas 3,4 ).

\section{Discusión}

La biomasa del fitoplancton (expresada como contenido de clorofila a) y la producción primaria mostraron un claro patrón incrementándose del norte (estación 137) hacia el sur (estación 36). Robles-Jarero y Lara-Lara (1993) reportaron la biomasa y las tasas de productividad para varias estaciones en el Golfo de Tehuantepec. Si comparamos sus datos con nuestros resultados encontramos una tendencia decreciente tanto de biomasa como de productividad del Golfo de Tehuantepec hacia la boca del Golfo de California. Las concentraciones de nutrientes no fueron significativamente diferentes en este transecto; sin embargo, las nutriclinas se registraron a profundidades más superficiales en las estaciones de la región sur. También, las estaciones en el Golfo de Tehuantepec estuvieron localizadas dentro de la plataforma continental, mientras que las estaciones en la región norte del transecto estuvieron localizadas a profundidades por debajo de los $1000 \mathrm{~m}$.

La profundidad de la zona eufótica y de la capa de mezcla tienen una importancia relevante para el fitoplancton, el cual recibe energía luminosa para efectuar sus funciones fisiológicas más importantes: fotosíntesis y crecimiento. Por otra parte, en regiones en donde las nutriclinas y termoclinas son muy superficiales se favorece el enriquecimiento de la zona eufótica con un mínimo esfuerzo de viento, incrementando la producción de estas áreas (Estrada y Blasco, 1985).

Debido a los vientos que actúan sobre la superficie del océano las termoclinas y nutriclinas del Pacífico oriental total chlorophyll and productivity at stations 36 through 121 , except at station 137 (mouth of the gulf) where the picoplankton fraction had the major contribution.

\section{Spatial variability of chlorophyll a and primary production}

Total chlorophyll $a$ ranged from 0.09 to $3.80 \mathrm{mg}$ Chl $a \mathrm{~m}^{-3}$, with a mean of $0.79 \mathrm{mg}$ Chla m $\mathrm{m}^{-3}$. The mean total primary production was $3.07 \mathrm{mg} \mathrm{C} \mathrm{m}^{-3} \mathrm{~h}^{-1}$ and varied from 0.15 to $17.10 \mathrm{mg} \mathrm{C} \mathrm{m}{ }^{-3} \mathrm{~h}^{-1}$. Maximum chlorophyll $a$ concentrations and primary production increased from north to south (stations 137 to 36). At all stations, nanophytoplankton contributed the highest percentage of chlorophyll $a$ content $(60-100 \%)$ and primary production (70-100\%).

\section{Integrated values of chlorophyll a and primary production}

The integrated euphotic zone chlorophyll $a$ contents ranged

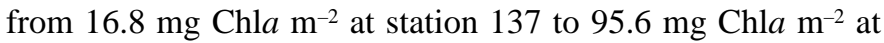
station 81 (table 2). Daily integrated primary production rates ranged from $0.15 \mathrm{~g} \mathrm{C} \mathrm{m}^{-2} \mathrm{~d}^{-1}$ at station 137 to $1.15 \mathrm{~g} \mathrm{C} \mathrm{m}^{-2} \mathrm{~d}^{-1}$ at station 81 (table 2). Nanophytoplankton had the major contribution at all the stations. Microphytoplankton was important ( $\sim 4 \%$ ) only at stations 81 and 121 . The contribution by the nanophytoplankton fractions was variable; however, the picoplankton had the maximum contribution ( 70\%) at station 137 at the mouth of the gulf (tables 3, 4).

\section{Discussion}

Phytoplankton biomass (expressed as chlorophyll $a$ content) and primary production rates showed a clear pattern, increasing from north (station 137) to south (station 36). Robles-Jarero and Lara-Lara (1993) reported biomass and productivity rates for several stations in the Gulf of Tehuantepec. If we compare their data with our results, a decreasing tendency is found, with the highest biomass and rates at the stations in the Gulf of Tehuantepec and the lowest at the mouth of the Gulf of California. Nutrient concentrations were not significantly different in this transect; however, nutriclines were registered at shallow depths of the southern stations. Also, the stations in the Gulf of Tehuantepec were located within the continental shelf, while the stations in the northern part of the transect were located at depths over $1000 \mathrm{~m}$.

The euphotic zone and mixing layer depths are very important for phytoplankton, which depend on light energy to perform their two most important physiological functions: photosynthesis and growth. In regions where nutriclines and thermoclines are very shallow, the euphotic zone is nutrientenriched with minimum wind effect, increasing the primary production of these areas (Estrada and Blasco, 1985).

As a result of wind stress on the ocean surface, the thermocline and nutricline depths of the eastern tropical Pacific have been reported to be shallower than in the western Pacific (Picaut, 1985). 
Tabla 2. Promedios y rangos de nutrientes, clorofila $a$ y producción primaria, y clorofila $a$ y producción primaria integradas a lo largo de la zona eufótica. Table 2. Mean values and ranges of nutrients, chlorophyll $a$ content and primary production rates, and integrated euphotic zone chlorophyll $a$ and primary production.

\begin{tabular}{rcccccc}
\hline Estación & $\begin{array}{c}\text { Fosfatos } \\
(\mu \mathrm{M})\end{array}$ & $\begin{array}{c}\text { Silicatos } \\
(\mu \mathrm{M})\end{array}$ & $\begin{array}{c}\text { Clorofila } a \\
\text { total promedio } \\
\left(\mathrm{mg} \mathrm{m}^{-3}\right)\end{array}$ & $\begin{array}{c}\text { Producción } \\
\text { total promedio } \\
\left(\mathrm{mg} \mathrm{C} \mathrm{m}^{-3} \mathrm{~h}^{-1}\right)\end{array}$ & $\begin{array}{c}\text { Clorofila } a \\
\text { integrada } \\
\left(\mathrm{mg} \mathrm{m}^{-2}\right)\end{array}$ & $\begin{array}{c}\text { Producción primaria } \\
\text { integrada } \\
\left(\mathrm{g} \mathrm{C} \mathrm{m}^{-2} \mathrm{~d}^{-1}\right)\end{array}$ \\
\hline 36 & $0.80(0.20-1.92)$ & $4.93(1.28-16.51)$ & $0.54(0.32-0.72)$ & $2.18(0.73-4.36)$ & 29.8 & 0.41 \\
104 & $1.31(0.66-2.04)$ & $11.44(3.85-23.21)$ & $0.83(0.10-2.06)$ & $4.47(0.34-10.13)$ & 39.0 & 0.64 \\
81 & $0.70(0.30-1.04)$ & $3.56(1.68-8.20)$ & $1.15(0.35-3.78)$ & $4.40(0.92-14.12)$ & 95.6 & 1.15 \\
121 & $0.92(0.20-2.40)$ & $4.86(0.49-21.34)$ & $1.06(0.65-1.92)$ & $3.93(0.25-10.43)$ & 56.34 & 0.79 \\
124 & $0.87(0.76-1.21)$ & $3.34(1.38-6.82)$ & $0.75(0.20-2.17)$ & $3.98(0.70-5.79)$ & 27.72 & 0.42 \\
128 & $0.87(0.54-1.83)$ & $3.69(0.69-12.94)$ & $0.95(0.67-1.11)$ & $1.65(0.49-3.50)$ & 24.91 & 0.17 \\
137 & $0.84(0.41-1.83)$ & $7.35(2.37-17.99)$ & $0.32(0.09-0.54)$ & $0.86(0.15-1.78)$ & 16.86 & 0.16 \\
\hline
\end{tabular}

Tabla 3. Distribución por clases de tamaño de la clorofila $a\left(\mathrm{mg} \mathrm{m}^{-2}\right)$ integrada a lo largo de la zona eufótica.

Table 3. Euphotic zone integrated chlorophyll $a\left(\mathrm{mg} \mathrm{m}^{-2}\right)$ distribution by size fractions.

\begin{tabular}{rccccc}
\hline \multirow{2}{*}{ Estación } & Comunidad total & $\begin{array}{c}\text { Microfitoplancton } \\
(>20 \mu \mathrm{m})\end{array}$ & \multicolumn{2}{c}{ Nanofitoplancton } & Picoplancton \\
\cline { 4 - 5 } & & 1.30 & 5.30 & 4.6 & 18.6 \\
\hline 36 & 29.80 & 11.20 & 10.90 & 4.3 & 12.5 \\
104 & 39.00 & 53.40 & 23.00 & 7.8 & 11.3 \\
81 & 95.60 & 21.53 & 13.79 & 3.96 & 13.39 \\
121 & 56.34 & 7.20 & 7.06 & 7.38 & 4.07 \\
124 & 27.72 & 7.96 & 2.88 & 6.52 & 7.20 \\
128 & 24.91 & 0.00 & 6.20 & 2.23 & 10.21 \\
137 & 16.86 & & & & $(<10->3 \mu \mathrm{m})$ \\
\hline
\end{tabular}

Tabla 4. Distribución por clases de tamaño de la producción primaria $\left(\mathrm{mg} \mathrm{C} \mathrm{m}^{-2} \mathrm{~d}^{-1}\right)$ integrada a lo largo de la zona eufótica. Table 4. Daily integrated primary production $\left(\mathrm{mg} \mathrm{C} \mathrm{m}^{-2} \mathrm{~d}^{-1}\right.$ ) distribution by size fractions.

\begin{tabular}{rccccc}
\hline \multirow{2}{*}{ Estación } & Comunidad total & $\begin{array}{c}\text { Microfitoplancton } \\
(>20 \mu \mathrm{m})\end{array}$ & \multicolumn{2}{c}{ Nanofitoplancton } & Picoplancton \\
\cline { 4 - 4 } & & & $(<20->10 \mu \mathrm{m})$ & $(<10->3 \mu \mathrm{m})$ & $(<3->0.45 \mu \mathrm{m})$ \\
\hline 36 & 0.41 & 0.11 & 0.18 & 0.01 & 0.13 \\
104 & 0.64 & 0.13 & 0.25 & 0.01 & 0.26 \\
81 & 1.15 & 0.51 & 0.24 & 0.16 & 0.25 \\
121 & 0.79 & 0.24 & 0.30 & 0.11 & 0.09 \\
124 & 0.42 & 0.08 & 0.06 & 0.15 & 0.09 \\
128 & 0.17 & 0.03 & 0.04 & 0.04 & 0.05 \\
137 & 0.16 & 0.01 & 0.03 & 0.02 & 0.11 \\
\hline
\end{tabular}


tropical se han registrado a profundidades más someras que las del océano medio o las de la región occidental (Picaut, 1987).

En general, los valores máximos de clorofila $a \mathrm{y}$ producción primaria se registraron al mismo nivel de irradiancia (22\% Eo), alrededor de $20 \mathrm{~m}$ de profundidad. Esto indica una clara respuesta a la disponibilidad de nutrientes, ya que las nutriclinas también se registraron a esta profundidad. Por otro lado, es probable que las condiciones de luz al 22\% de Eo se hayan aproximado al óptimo de irradiancia dada la disponibilidad de nutrientes, favoreciendo la fotosíntesis a esa profundidad.

Durante nuestro estudio las concentraciones de fosfatos y silicatos fueron mayores que las reportadas previamente para aguas oceánicas del Pacífico oriental tropical (Love, 1972; Love y Allen, 1975; Gaxiola-Castro y Álvarez-Borrego, 1986). Esto era de esperarse, ya que nuestras estaciones estuvieron localizadas en sitios más cercanos a la costa. Nuestras estaciones más al sur están localizadas en una región que es influenciada por el transporte de agua de áreas de grandes afloramientos de nutrientes. Estas áreas son el Domo de Costa Rica (Wyrtki, 1964; Broenkow, 1965) y el Golfo de Tehuantepec (Blackburn, 1962). Ambos son centros de surgencias estacionales que proporcionan grandes cantidades de nutrientes que son transportados hacia la región de estudio por la Corriente Norecuatorial y la Corriente Costera de Costa Rica.

En el transecto estudiado el nanofitoplancton tuvo la mayor contribución ( $60 \%$ a $100 \%)$ a la biomasa y a la producción del fitoplancton. Robles-Jarero y Lara-Lara (1993) también encontraron una contribución del nanofitoplancton de cerca de $70 \%$ para estaciones en el Golfo de Tehuantepec. Tal como ha sido previamente reportado, estas células tienen altas tasas de división, altas eficiencias fotosintéticas y altas tasas de asimilación (Malone y Neale, 1981; Takahashi y Bienfang, 1983; Yentsch y Phinney, 1989).

Zeitzschel (1969) reportó valores de producción primaria de incubaciones de medio día (6 h) para la boca del Golfo de California. Los valores integrados tuvieron un rango de 0.45 a $0.95 \mathrm{~g} \mathrm{C} \mathrm{m}^{-2} \mathrm{~d}^{-1}$ en noviembre y diciembre. Sin embargo, estos datos no son directamente comparables con los nuestros debido a que las incubaciones de corto plazo dan mayores tasas de producción que las de largo plazo (Carpenter y Lively, 1980). Gaxiola-Castro y Álvarez-Borrego (1986) reportaron tasas de productividad de dos estaciones cerca de la entrada al golfo para enero, con un rango de 0.19 a $1.40 \mathrm{~g} \mathrm{C} \mathrm{m}^{-2} \mathrm{~d}^{-1}$. Nuestras dos estaciones cercanas a la entrada del golfo (estaciones 137 y 128) registraron valores de producción de 0.15 y $0.16 \mathrm{~g} \mathrm{C} \mathrm{m}^{-2} \mathrm{~d}^{-1}$, respectivamente. Probablemente, las estaciones estudiadas por Gaxiola-Castro y Álvarez-Borrego (1986) tuvieron una mayor influencia de las aguas del Domo de Costa Rica, las cuales son ricas en nutrientes, ya que estuvieron situadas en aguas más oceánicas que las nuestras.

Leet y Stevenson (1969) midieron la producción primaria superficial para la región entre Mazatlán, Cabo San Lucas y las islas Tres Marías, y obtuvieron valores entre $1.3 \mathrm{y}$ $38.8 \mathrm{mg} \mathrm{C} \mathrm{m}^{-3} \mathrm{~d}^{-1}$ de abril a agosto. Owen y Zeitzschel (1970)
In general, the chlorophyll and primary production maxima were reached at the same irradiance level (22\% Eo) about $20 \mathrm{~m}$ depth. This indicates a clear response to nutrient availability, because nutriclines were also registered at this depth. On the other hand, probably the light conditions at 22\% Eo were also close to the optimum irradiance for phytoplankton, increasing their production at that depth.

During our study, the phosphate and silicate concentrations were higher than values previously reported for oceanic waters of the eastern tropical Pacific (Love, 1972; Love and Allen, 1975; Gaxiola-Castro and Álvarez-Borrego, 1986). This was expected, because our stations were located close to the coastal zone. Our southernmost stations are located in a region that is influenced by downstream transport from areas of high nutrient supply. These areas are the Costa Rica Dome (Wyrtki, 1964; Broenkow, 1965) and the Gulf of Tehuantepec (Blackburn, 1962). Both are centers of seasonal upwelling supplying large quantities of nutrients, which are transported to the study region by the North Equatorial Current and the Costa Rica Coastal Current.

Nanophytoplankton had the major contribution ( $60 \%$ to $100 \%)$ to the phytoplankton biomass and productivity in the study region. Robles-Jarero and Lara-Lara (1993) also reported a contribution by nanophytoplankton of about $70 \%$ for the stations in the Gulf of Tehuantepec. As has been previously reported, these cells have higher division rates, high photosynthetic efficiencies and high assimilation rates (Malone and Neale, 1981; Takahashi and Bienfang, 1983; Yentsch and Phinney, 1989).

Zeitzschel (1969) reported primary productivity rates from half-day incubations (6 h) for the mouth of the Gulf of California. The integrated values ranged from 0.45 to $0.95 \mathrm{~g} \mathrm{C} \mathrm{m}^{-2} \mathrm{~d}^{-1}$ for November and December; however, these data are not directly comparable to ours because short-term incubations produce greater production rates than long-term ones (Carpenter and Lively, 1980). Gaxiola-Castro and Álvarez-Borrego (1986) reported primary productivity rates for two stations close to the entrance of the gulf in January, ranging from 0.19 to $1.40 \mathrm{~g} \mathrm{C} \mathrm{m}^{-2} \mathrm{~d}^{-1}$. Our two stations close to the entrance (stations 137 and 128 ) registered primary production rates of 0.15 and $0.16 \mathrm{~g} \mathrm{C} \mathrm{m}^{-2} \mathrm{~d}^{-1}$, respectively. Probably, Gaxiola-Castro and Álvarez-Borrego's (1986) stations were more influenced by the Costa Rica Dome waters, which are richer in nutrients, because they were located in more oceanic waters than ours.

Leet and Stevenson (1969) measured surface primary production for the region between Mazatlán, Cabo San Lucas and the Tres Marías islands, and their values ranged from 1.3 to $38.8 \mathrm{mg} \mathrm{C} \mathrm{m}^{-3} \mathrm{~d}^{-1}$ for April to August. Owen and Zeitzschel (1970) reported an average annual cycle for the eastern tropical Pacific of 0.13 to $0.32 \mathrm{~g} \mathrm{C} \mathrm{m}^{-2} \mathrm{~d}^{-1}$, with maximum productivity in early spring and a secondary peak in August and September. For the southernmost part of our study area, they reported averaged productivity values of $0.14 \mathrm{~g} \mathrm{C} \mathrm{m}^{-2} \mathrm{~d}^{-1}$ for December and January. For this same region, Gaxiola-Castro and 
reportaron para el Pacífico oriental tropical un ciclo anual promedio de 0.13 a $0.32 \mathrm{~g} \mathrm{C} \mathrm{m}^{-2} \mathrm{~d}^{-1}$, con máxima productividad a principios de primavera y un pico secundario en agosto y septiembre. Para la región más sureña de nuestra área de estudio, ellos reportaron valores de producción de $0.14 \mathrm{~g} \mathrm{C} \mathrm{m}^{-2} \mathrm{~d}^{-1}$, en promedio, para diciembre y enero. Para esta misma región, Gaxiola-Castro y Álvarez-Borrego (1986) reportaron valores medios de productividad para enero de 0.30 a $0.54 \mathrm{~g} \mathrm{C} \mathrm{m}^{-2} \mathrm{~d}^{-1}$. Nuestros valores para las estaciones 121 y 124 fueron 0.79 y $0.42 \mathrm{~g} \mathrm{C} \mathrm{m}^{-2} \mathrm{~d}^{-1}$, respectivamente. Como se puede apreciar, nuestros valores están dentro del rango de valores registrados por otros autores para esta región.

En resumen, nuestros valores de producción primaria para la región cercana a la boca del golfo fueron más bajos que valores previamente reportados, pero para estaciones más al sur nuestros valores fueron mayores. Probablemente, las altas concentraciones de clorofila $a$ y altas tasas de producción primaria en la región sur lo fueron en respuesta a las altas concentraciones de nutrientes registradas en este periodo, así como a las nutriclinas más superficiales que las de las estaciones más el norte. Es importante también notar la mayor contribución del nanofitoplancton que la del microfitoplancton a la biomasa y la producción primaria de esta región de México. En otras regiones, por ejemplo en el Golfo de California, Lara-Lara y Valdez-Holguín (1989) reportaron también contribuciones del nanofitoplancton similares a las medidas en este trabajo.

\section{Agradecimientos}

Agradecemos a Joaquín García su apoyo con la batimetría, a J.M. Domínguez y F. Ponce su apoyo en la elaboración de las figuras, y al capitán y tripulación del B/O El Puma de la UNAM su colaboración durante el muestreo.

\section{Referencias}

Blackburn, M. (1962). An oceanographic study of the Gulf of Tehuantepec. US Fish and Wildlife Service, Special Scientific Reports, Fisheries, No. 404, 28 pp.

Broenkow, W.W. (1965). The distribution of nutrients in the Costa Rica Dome in the eastern tropical Pacific. Limnol. Oceanogr., 10: 40-52.

Carpenter, E.J. and Lively, J.S.S. (1980). Review of estimates of algal growth using ${ }^{14} \mathrm{C}$ tracer techniques. In: P.G. Falkowski (ed.), Primary Productivity in the Sea. Plenum Press, New York.

Cole, B.E., Cloern, J.E. and Alpine, A.E. (1986). Biomass and productivity of three phytoplankton size classes in San Francisco Bay. Estuaries, 9: 117-126.

Estrada, M. and Blasco, D. (1985). Phytoplankton assemblages in coastal upwelling areas. Simposio internacional sobre las áreas de afloramiento más importantes del Oeste Africano (Cabo Blanco y Benguela). Ins. Inv. Pesq., Barcelona, 1: 379-402.

Gaxiola-Castro, G. and Álvarez-Borrego, S. (1986). Primary productivity of the Mexican Pacific. Cienc. Mar., 12: 26-33.

Glover, H.E., Smith, A.E. and Shapiro, L. (1985). Diurnal variations in photosynthetic rates: Comparisons of ultraphytoplankton size fraction. J. Plankton Res., 7: 519-535.

Grasshoff, K., Erhardt, M. and Kremling, K. (1983). Methods of Seawater Analyses. Verlag Chemie, 419 pp.
Álvarez-Borrego (1986) reported average productivity values for January of 0.30 to $0.54 \mathrm{~g} \mathrm{Cm}^{-2} \mathrm{~d}^{-1}$. Our values for stations 121 and 124 were 0.79 and $0.42 \mathrm{~g} \mathrm{C} \mathrm{m}^{-2} \mathrm{~d}^{-1}$, respectively. It is clear that our values are within the range of values previously reported by other authors for this region.

In summary, our primary production rates for the region close to the mouth of the Gulf of California were lower than values previously reported, but higher for our southernmost stations in the Gulf of Tehuantepec. Probably, the higher biomass and productivity rates in the southern region were in response to the higher nutrient concentrations measured during this period; nutriclines were also shallower than at stations in the northern region. It is also important to note the greater contribution by the nanophytoplankton than the microphytoplankton in this area of Mexico. In other regions of Mexico, such as the Gulf of California, Lara-Lara and Valdez-Holguín (1989) registered contributions to the biomass and primary production by the nanophytolankton similar to the ones reported in this study.

\section{Acknowledgements}

We thank Joaquín García for his support with the bathymetric data, J.M. Domínguez and F. Ponce for their support with the graphic work, and the captain and crew of the R/V El Puma of UNAM for their collaboration during the sampling period.

English translation by the authors.

Harris, G. P., Griffiths, F.B., Clementson, L.A., Lyne, V. and Van der Doe, H. (1991). Seasonal and interannual variability in physical processes, nutrient cycling and the structure of the food chain in Tasmanian Shelf waters. J. Plankton Res., 13 (Suppl.): 109-131.

Hopcroft, R.R. and Roff, J.C. (1990). Phytoplankton size fractions in a tropical neritic ecosystem near Kingston Jamaica. J. Plankton Res., 12: 1069-1088.

Lara-Lara, J.R. y Valdez-Holguín, J.E. (1989). Biomasa y productividad primaria del Golfo de California por fracción de tamaños durante primavera de 1984. Cienc. Mar., 14: 1-14.

Leet, W.S. and Stevenson, M.R. (1969). Oceanographic observations from the Mazatlán project: October-August 1967. Data Rep. Inter. Am. Trop. Tuna Comm., 3: 249 pp.

Love, C.M. (ed.) (1972). EASTROPAC Atlas. Vol. 6, Circ. 330, Washington, DC.

Love, C.M. and Allen, R. (eds.) (1975). EASTROPAC Atlas. Vol. 10, Circ. 330, Washington, DC.

Malone, T.C. (1971). The relative importance of nanophytoplankton and netplankton as primary producers in tropical oceanic and neritic phytoplankton communities. Limnol. Oceanogr., 16: 633-639.

Malone, T.C. (1980). Size-fractionated primary productivity of marine phytoplankton. In: P.G. Falkowski (ed.), Primary Productivity in the Sea. Brookhaven Symposia in Biology, 31: 301-309.

Malone, T.C. and Neale, P.J. (1981). Parameters of light dependent photosynthesis for phytoplankton size fractions in temperate estuarine and coastal environments. Mar. Biol., 61: 289-297.

Owen, R.W. and Zeitzschel, B. (1970). Phytoplankton production. Seasonal change in the oceanic eastern tropical Pacific. Mar. Biol., 7: 32-36. 
Picaut, J. (1985). Major dynamics affecting the Eastern Atlantic and Pacific. CalCOFI Rep., 26: 41-50.

Platt, T., Subba Rao, D.V. and Irwin, B. (1983). Photosynthesis of picoplankton in the oligotrophic ocean. Nature, 301: 702-704.

Robles-Jarero, E.G. and Lara-Lara, J.R. (1993). Phytoplankton biomass and primary productivity by size classes in the Gulf of Tehuantepec, Mexico. J. Plankton Res., 15: 1341-1358.

Steemann-Nielsen, E. (1952). The use of radioactive carbon $\left({ }^{14} \mathrm{C}\right)$ for measuring organic production in the sea. J. Cons. Perm. Int. Explor. Mer, 8: 117-140.

Strickland, J.D.H. and Parsons, T.R. (1972). A Practical Handbook of Seawater Analysis. 2nd ed. Bull. Fish. Res. Board Can., 67, 311pp.
Takahashi, M. and Bienfang, P.K. (1983). Size structure of phytoplankton biomass and photosynthesis in subtropical Hawaiian waters. Mar. Biol., 76: 203-211.

Walsh, J.J. (1976). Herbivory as factor in patterns of nutrient utilization in the sea. Limnol. Oceanogr., 21: 1-13.

Wyrtki, K. (1964). Upwelling in the Costa Rica Dome. US Fish and Widlife Service. Fish. Bull., 63: 355-372.

Yentsch, C.S. and Menzel, D.W. (1963). A method for the determination of phytoplankton chlorophyll and phaeophytin by fluorescence. Deep-Sea Res., 10: 1221-1231.

Yentsch, C.S. and Phinney, D. A. (1989). A bridge between optics and microbial ecology. Limnol. Oceanogr., 34: 1694-1705.

Zeitzschel, B. (1969). Primary productivity in the Gulf of California. Mar. Biol., 3: 201-207. 